Original Article

\title{
Study on Correlation Between Serum Prostate Specific Antigen and Various Prostatic Pathology
}

\author{
Nirajan Mainali ${ }^{1}$, Niraj Nepal', Prabesh kumar Chaudhary', Jit Shrestha ${ }^{2}$ \\ ${ }^{1}$ Department of Pathology, Nobel Medical College, Biratnagar, Nepal. \\ ${ }^{2}$ Department of Urology, Nobel Medical College, Biratnagar, Nepal.
}

\section{ABSTRACT}

Introduction: Prostatic enlargement that may due to any cause may give rise to bladder outlet obstruction. Prostatic specific antigen is the enzyme that is responsible for liquefaction of semen within a few minutes after it has clotted. Prostatic specific antigen is a widely used tumor marker for prostatic cancer. Prostatic specific antigen levels in the blood go up if the barrier between the lining epithelium and the blood stream is damaged. This study was done to determine the correlation between serum Prostatic specific antigen level and histological diagnosis in prostatic biopsy.

Materials and Methods: This is a one year prospective study carried out in the Department of Pathology, Nobel Medical College from August 16, 2016 to August 15, 2017. A total of 175 cases were included in the study. Patient Prostatic specific antigen level were noted and biopsy specimen was collected after operation. Histopathological examination was done and correlation between HPE diagnosis and serum Prostatic specific antigen level was done.

Results: Benign Prostatic Hyperplasia was the most common diagnosis that was encountered .Majority of the cases had a serum Prostatic specific antigen level less than $10 \mathrm{ng} / \mathrm{ml}$. Serum Prostatic specific antigen level of more than $30 \mathrm{ng} / \mathrm{ml}$ was seen only in prostatic carcinoma.

Conclusion: Serum Prostatic specific antigen is organ specific but not a disease for prostate. It can be used to monitor the carcinoma of the prostate rather than the diagnosis of the carcinoma.

Keywords: Benign; Carcinoma; Hyperplasia; Prostate; Prostate specific antigen; Prostatic
Copyright: This is an open-access article distributed under the terms of the Creative Commons Attribution 4.0 International License, which permits unrestricted use, distribution, and reproduction in any medium, provided the original author and source are credited.

\section{Correspondence:}

Dr. Nirajan Mainali, MBBS, MD

Assistant Professor, Department of Pathology

Nobel Medical College Teaching Hospital

Kanchanbari-4, Biratnagar, Nepal

ORCID ID: 0000-0002-6648-1914

Email: mainali_nirajan@hotmail.com

Submitted: $15^{\text {th }}$ June 2018

Accepted: $10^{\text {nd }}$ September 2018

Published: $1^{\text {st }}$ December 2018

\section{Conflict of Interest: None}

Source of Support: None

Citation: Mainali N, Nepal N, Choudhary PK, Shrestha J. Study on correlation between serum prostate specific antigen and various prostatic pathology. Nep Med J 2018;1:70-3. DOI: 10.3126/ nmj.v\%vi\%i.21579

\section{INTRODUCTION}

Prostate is fibro-musculo-glandular organ which is located around the neck of the urinary bladder. Prostatic enlargement that may due to any cause may give rise to bladder outlet obstruction. ${ }^{1}$ It is a male specific organ and the rate of clinical symptoms due to obstruction of the bladder neck goes up as the age rises due to increase in prostatic volume. ${ }^{2}$ Prostate specific antigen (PSA), a glycoprotein serine protease, which was first identified by Wang et al in $1979 .{ }^{3}$

PSA is the enzyme that is responsible for liquefaction of semen within a few minutes after it has clotted. ${ }^{4}$ Prostate - specific Antigen (PSA) is a widely used tumor marker for prostatic cancer. 
Table 1: Age distribution of patients with different diagnosis of prostatic biopsy

\begin{tabular}{|c|c|c|c|c|c|c|}
\hline Age Group (Years) & ВРН & $\begin{array}{c}\text { BPH with chronic } \\
\text { prostatitis }\end{array}$ & LGPIN & HGPIN & $\begin{array}{c}\text { Carcinoma } \\
\text { Prostate }\end{array}$ & Total (\%) \\
\hline$\leq \mathbf{5 0}$ & 04 & 01 & 00 & $\mathbf{0 0}$ & 00 & 05 (2.85) \\
\hline $51-60$ & 17 & 01 & 02 & 00 & 01 & $21(12.00)$ \\
\hline $61-70$ & 59 & 13 & 05 & 03 & 02 & $82(46.85)$ \\
\hline $71-80$ & 34 & 10 & 01 & 03 & 05 & $53(30.28)$ \\
\hline $81-90$ & 03 & 02 & 00 & 01 & 06 & $12(6.85)$ \\
\hline$\geq 91$ & 00 & 01 & 00 & 00 & 01 & $02(1.14)$ \\
\hline Total numbers (\%) & $117(66.85)$ & $28(16)$ & 08 (4.57) & $07(4.00)$ & $15(8.57)$ & $175(100 \%)$ \\
\hline
\end{tabular}

Table 2: Serum PSA levels in different prostatic lesions.

\begin{tabular}{|c|c|c|c|c|c|c|}
\hline PSA level (ng/ml) & ВPH & $\begin{array}{c}\text { BPH with chronic } \\
\text { prostatitis }\end{array}$ & LGPIN & HGPIN & $\begin{array}{c}\text { Carcinoma } \\
\text { Prostate }\end{array}$ & Total (\%) \\
\hline $0-4$ & 72 & 04 & 04 & 02 & 01 & $83(47.42)$ \\
\hline 4.1-10 & 39 & 19 & 04 & 03 & 03 & $68(38.86)$ \\
\hline $10.1-20$ & 04 & 04 & 00 & 02 & 02 & $12(6.85)$ \\
\hline 20.1-30 & 02 & 01 & 00 & 00 & 05 & $08(4.57)$ \\
\hline$>\mathbf{3 0}$ & 00 & 00 & 00 & 00 & 04 & $04(2.28)$ \\
\hline Total numbers (\%) & $117(66.85)$ & $28(16)$ & 08 (4.57) & 07 (4.00) & $15(8.57)$ & $175(100 \%)$ \\
\hline
\end{tabular}

PSA levels in the blood go up if the barrier between the lining epithelium and the blood stream is damaged. PSA is a prostatic specific but it does not specify the type of the disease. ${ }^{5}$ Benign prostatic hyperplasia, urethral or prostatic trauma, and prostatitis, along with prostate cancer, can all be associated with elevated serum PSA levels. Ejaculation and digital rectal examinations can even increase PSA levels but studies have shown the effects to be variable or insignificant. ${ }^{6}$

This study was done to determine the correlation between serum PSA level and histological diagnosis in prostatic biopsy. The aim of this study was to evaluate the utility of PSA assay as a method of investigation in diagnosis of prostatic lesions and to correlate with morphological types of pathological lesions.

\section{MATERIALS AND METHODS}

This is a one year prospective study carried out in the Department of Pathology, Nobel Medical College from August 16, 2016 to August 15 2017. Prior to study, permission was obtained from institutional review committee. All the patients who gave consent for the study and had transurethral removal of prostate were included in the study except those who were taking treatments before for any prostatic disease like 5 alpha reductase inhibitors, gonadotropin releasing hormone agonist or those who were having diabetes mellitus or neurological disorder that can alter bladder dyanamics

After inclusion in the study, patient PSA level was noted and biopsy specimen was collected after operation. Biopsy specimens were fixed with $10 \%$ formalin and were processed and Hematoxylin and Eosin stain was used for histopathological examination. Diagnostic criteria for Prostatic carcinoma, prostatitis, benign nodular hyperplasia and prostatic intraepithelial neoplasia (low grade/ high grade) were made as per guidelines laid down by World Health Organization 2004. Serum PSA level was measured using chemiluminescent assay

\section{RESULTS}

A Total of 175 patients were included in the study. Age of the patients ranged from 47 to 96 years (mean age 66.2 years). Diagnoses that were made were Benign Prostatic Hyperplasia $(\mathrm{BPH}), \mathrm{BPH}$ with Prostatitis, Low grade intraepithelial lesion, high grade intra epithelial lesions and prostatic adenocarcinoma. Most frequent diagnosis was that of BPH contributing a total of 116 patients $(66.85 \%)$. High grade prostatic intraepithelial lesion was the least frequent diagnosis that was encountered contributing only total of 7 cases $(4 \%)$. Adenocarcinoma of Prostate contributed in a total of 15 cases $(8.57 \%)$. Majority of the patients were in between the age 61-70 years of age with the majority of the patients showing histopathological diagnosis of BPH (Table 1). A total of 14 patients were included in the study with the age group of $>80$ years. $7(50 \%)$ of the patients were those of Carcinoma Prostate.

When the Serum PSA level was correlated with the histopathological diagnosis, majority of the patients show Serum PSA level less than $4 \mathrm{ng} / \mathrm{ml}$. 83/175 (43.42\%) patient's serum PSA level was in that range. 72/83 Patient were those of Benign Prostatic Hyperplasia. Out of the 117 Benign Prostatic Hyperplasia patient's 109 patient PSA value was less than $10 \mathrm{ng} / \mathrm{ml}$. None of the patient have a serum PSA level more than $30 \mathrm{ng} / \mathrm{ml}$. (Table 2) Twenty three of 28 patients whose diagnosis was Benign Prostatic Hyperplasia with Chronic Prostatitis, showed serum PSA level less than $10 \mathrm{ng} / \mathrm{ml}$. All the patients $(\mathrm{n}=8)$ with a histopathological diagnosis of low grade prostatic intraepithelial lesion had a serum PSA level less than $10 \mathrm{ng} / \mathrm{ml} .5 / 7$ patient's with a histopathological diagnosis of high grade prostatic intraepithelial lesion had a serum PSA level of less than $10 \mathrm{ng} / \mathrm{ml}$. Whereas 4/15 (26.67\%) of the patients with prostatic adenocarcinoma had a serum PSA level less than $10 \mathrm{ng} / \mathrm{ml}$. A total of 4 patients had a Serum PSA level more than $30 \mathrm{ng} / \mathrm{ml}$. All of them were those of prostatic adenocarcinoma. 


\section{DISCUSSION}

Enlargement of prostate is one of the most common problem encountered in the male patients above 50 years. One of the study showed that the percentage of male with enlargement of prostate increseases from $20 \%$ at 40 years of age to $70 \%$ by age 60 and $90 \%$ by eighth decade of life. ${ }^{7}$

In our study, age group of the patient was from 47 to 96 years with the mean age of 66.2 years, where as in the study done by Hirachand et $\mathrm{al}^{8}$, age group of the patient was $46-88$ years with the mean age of 68 years which is similar to the study done by Mansoor I, Lakhey M et al, Lokuhetty MD et al an Josephine A $(65.55,67.61,69.7,65,5$ years $){ }^{9-12}$

Benign Prostatic Hyperplasia was the most common diagnosis in our study $(\mathrm{n}=117,66.85 \%)$ which was similar to the study done by Hirachand et al8, Alpesh M et al13 and Lakhey et al. ${ }^{9}$

Fifteen (8.57\%)cases of Prostatic Adenocarcinoma were included in our study which was slightly less than in the study done by Banerjee B et al ${ }^{14}$ and Wadgaonkar et al. ${ }^{15}$ Fifteen $(8.57 \%)$ cases were those of Prostatic intra epithelial neoplasia which was slightly less than the study done by Hirachand et $\mathrm{al}^{8}$, Banerjee $\mathrm{B}$ et $\mathrm{l}^{14}$ and Maru et al. ${ }^{13}$

Prostatic Specific Antigen is produced only by the lining cells of prostatic acini and prostatic tissue. Since it is produced only by prostate, it is considered as the serum marker for Prostatic carcinoma. Unfortunately PSA is specific for prostate but not for the prostatic disease. Its concentration was also found to increase in BPH, PIN and Prostatitis. Recent reports from Prostate, Lung, Colorectal and Ovarian Cancer screening Trial (PLCO) and the European Randomized Study of Screening for Prostate Cancer (ERSPC) doubted the benefit of PSA screening. ${ }^{16,17} 26.67 \%$ of the total Patient with Prostatic carcinoma had a Serum PSA level less than $10 \mathrm{ng} / \mathrm{ml}$. In a study done by Alpesh et al ${ }^{13}, 8 \%$ of the patient's with prostatic adenocarcinoma had serum PSA level less than $10 \mathrm{ng} / \mathrm{ml}$. In Our study, serum PSA level with more than $30 \mathrm{ng} / \mathrm{ml}$ was present in only in case of Prostatic carcinoma, Serum PSA level with more than $20 \mathrm{ng} / \mathrm{ml}$ was positively correlated with Prostatic carcinoma. In the study done by Kamaleshwaran et al, $94.87 \%$ of the total BPH patient have a serum PSA level less than $10 \mathrm{ng} / \mathrm{ml} .18$ In the study done by Hirachand et al8, 73.43\% had a serum PSA level less than $7 \mathrm{ng} / \mathrm{ml}$.

In this study, all 8 cases of LPIN has a serum PSA level less than $10 \mathrm{ng} / \mathrm{ml}$ whereas $2 / 7$ cases of HPIN has serum PSA level more than $10 \mathrm{ng} / \mathrm{ml}$. In the study done by Hirachand et al $61.54 \%$ of PIN. There was a statistical difference in the serum PSA level in the $\mathrm{BPH}$ and carcinoma Prostate in the study done by Udeh et $\mathrm{al}^{19}$ where as in other study there was an significant overlapping of the serum PSA level in between the BPH and carcinoma prostate. ${ }^{20,21}$ Some of the studies have showed that the serum PSA level varies as per tissue volume rather than histopathological diagnosis. ${ }^{22}$

\section{CONCLUSIONS}

Extreme high level of serum PSA is significant for carcinoma prostate, but since the carcinoma prostate significantly had low serum PSA level it cannot be used as diagnostic tool but as a monitoring tool it can be used

\section{REFERENCES}

1. Begum Z AA, Tengli MB, Ahmed MM. Study of various histopathological patterns in TURP specimens and incidental detection of carcinoma prostate. Indian J Pathology and oncology. 2015;2:303-8. Crossref

2. Konwar R, Chattopadhyay N, Bid HK. Genetic polymorphism and pathogenesis of benign prostatic hyperplasia. BJU Int. 2008;102(5):536-44. Crossref

3. Wang MC, Valenzuela LA, Murphy GP, Chu TM. Purification of a human prostate specific antigen. Invest urol. 1979;17(2):159-63. Crossref

4. Oesterling JE, Jacobsen SJ, Chute CG, Guess HA, Girman CJ, Panser LA, et al Serum prostate-specific antigen in a community-based population of healthy men. Establishment of age-specific reference ranges. Jama. 1993;270(7):8604. Crossref

5. Fitzpatrick JM. PSA measurement in the treatment of BPH. BJU Int. 2004;93 Suppl 1:2-4. Crossref

6. Tchetgen MB OJ. The effect of prostatitis, urinary retention, ejaculation, and ambulation on the serum prostate-specific antigen concentration. Urol Clin North Am. 1997;24:283-91. Crossref

7. Bid HK, Konwar R, Singh V. Benign prostatic hyperplasia: is it a growing public health concern for India? Indian J Med Sci. 2008;62(9):373-4. Crossref . Hirachand S, Pradhanang S, Acharya S. Study of prostatic pathology and its correlation with prostate specific antigen. J Pathol Nep. 2017;7:1074-7. Crossref

9. Lakhey M, Shrestha R, Bhatta AD. Correlation of serum free prostate- specific antigen level with histological findings in patients with prostatic disease. Kathmandu Univ Med J. 2010;8:158-63. Crossref

10. Mansoor I. Pattern of prostatic diseases in Saudi Arabia. The internet journal of Pathology 2003;2:1528-831.
11. Lokuhetty MD, Wijesinghe HD, Abeysuriya DT, Samarasinghe UC, Perera ND. Trans rectal ultra sound guided prostate biopsies: a single centre experience in Sri Lanka. Ceylon Med J. 2009;54(1):6-9. Crossref

12. Josephine A. Clinicopathological study of prostatic biopsies. J Clin Diagn Res. 2014;8(9):20. $\underline{\text { Crossref }}$

13. 16. Maru AM MH, Lakum NR, Chokshi T, Agnihotri A, Trivedi N, et al. Study on correlation between prostate specific antigen and various prostatic pathology. . Int J Med Sci Public Health 2014;3:735-7. Crossref

14. Banerjee B IB, Kumar H, Kambale T, Bavikar R. . Correlation between prostate specific antigen levels and various prostatic pathologies. J Med Soc 2016;30:172-5. Crossref

15. Wadgaonkar AR PA, Mahajan SV, Yengantiwar RP. . Correlation of serum prostate specific antigen level in various prostatic pathology in elderly men. Int J Basic Appl Med Sci 2013;3:274-81.

16. Andriole GL, Crawford ED, Grubb RL, 3rd, Buys SS, Chia D, Church TR, et al. Mortality results from a randomized prostate-cancer screening trial. The New England journal of medicine. 2009;360(13):1310-9. Crossref

17. Schroder FH, Hugosson J, Roobol MJ, Tammela TL, Ciatto S, Nelen V, et al. Screening and prostate-cancer mortality in a randomized European study. The New England journal of medicine. 2009;360(13):1320-8. Crossref

18. Kamaleshwaran KK MB, Harisankar CN, Bhattacharya A, Singh SK MA. Predictive value of serum prostate specific antigen in detecting bone metastasis in prostate cancer patients using bone scintigraphy. Indian J Nucl Med 2012;27:81-4. Crossref

19. Udeh EI, Nnabugwu, II, Ozoemena FO, Ugwumba FO, Aderibigbe AS, Ohayi SR, et al. Prostate-specific antigen density values among patients with symptomatic prostatic enlargement in Nigeria. World J Surg Oncol. 2016;14(1):916-21. Crossref 
20. Wolff JM, Boeckmann W, Effert PJ, Handt S, Jakse G. Evaluation of patients with diseases of the prostate using prostate-specific antigen density. $\mathrm{Br}$ urol.1995;76(1)41-6. Crossref

21. Gohji K, Nomi M, Egawa S, Morisue K, Takenaka A, Okamoto M, et al Detection of prostate carcinoma using prostate specific antigen, its density, and the density of the transition zone in Japanese men with intermediate serum prostate specific antigen concentrations. Cancer. 1997;79(10):1969-76. Crossref
22. Chung BH HS, Cho JS, Seong DH. Relationship between serum prostatespecific antigen and prostate volume in Korean men with benign prostatic hyperplasia: a multicentre study. BJU International. 2006;97(4):742-6. $\underline{\text { Crossref }}$ 